\title{
Exploring the Online EFL Classroom Ecology of Middle Schools During the COVID-19 Lockdown
}

\author{
Shuang Zhao \\ College of Humanities and Social Sciences, Harbin Institute of Technology, Shenzhen, China \\ Luying Zhang \\ College of Humanities and Social Sciences, Harbin Institute of Technology, Shenzhen, China \\ Yang Chen \\ College of Humanities and Social Sciences, Harbin Institute of Technology, Shenzhen, China
}

\begin{abstract}
The outbreak of COVID-19 has induced an abrupt shift from face-to-face instruction to online delivery mode for academic continuity. This research aims to explore the ecology of the pandemic-induced online English as foreign language (EFL) classrooms in Chinese middle schools and perceptions held by the English teachers, students, and parents. By analyzing data collected from 10, 576 questionnaires and eleven interviews, this study revealed how these participants played their respective parts in online EFL classroom ecology. Also, it was found that teachers' evaluations of students' learning performance (learning engagement and outcomes) and teacher-student interactions (in-class interaction, after-class interaction, and teachers' feedback about homework) and their overall satisfaction of the online EFL classrooms were lower than that of the other two groups. In addition, major concerns of the participants about online EFL teaching and learning were identified, such as students' vision damage and inadequate self-discipline, lack of face-to-face communication, and unstable Internet connection. Through presenting and discussing the research findings, this study is expected to provide implications and insights for foreign language educators, learners, and parents worldwide in adapting to online classrooms during public crises.
\end{abstract}

Index Terms—classroom ecology, EFL, participation, perceptions, COVID-19

\section{INTRODUCTION}

The COVID-19 pandemic impacted instructional delivery and academic continuity all over the world in early 2020 (Moser et al., 2020). Online education was considered an effective alternative to traditional classroom teaching during the pandemic because of its flexibility in time and place (Dong et al., 2020; Moser et al., 2021; Yang et al., 2020). However, in the field of foreign language education, which requires multiple interactional opportunities (Cui, 2021), insufficient research is conducted on how English as foreign language (EFL) courses are delivered online during the COVID-19 crisis. Existing studies have paid attention to college teachers' or students' experiences in and perceptions of online classes (Osamudiamen et al., 2021; Patricia, 2020), but little is known in middle school settings. How educators, students, and even parents reacted to the abrupt shift to online EFL education modes in middle schools is underresearched.

In China, an emergency plan called "Suspending Classes without Learning Termination (SCWLT)" was launched in February 2020. By April $8^{\text {th }}, 2020$, it was reported that about 270 million students in China have been engaged in online classes during the COVID-19 lockdown (Cen et al., 2020). This study was conducted in the city of Yichang, which is a middle-sized city of Hubei province with 401.76 million population and $300 \mathrm{~km}$ away from Wuhan. The city was locked from January $25^{\text {th }}$ to March $13^{\text {th }}, 2020$. Under this context, this study intends to (1) promote a better understanding of online EFL classroom ecology of middle schools in China during the lockdown, (2) enrich the ecological education theory by taking parents, another key role of online education, into consideration, and (3) provide insights for formulating worldwide educational countermeasures during the pandemic. In order to achieve the above three goals, we adopt quantitative and qualitative methods and propose the following two research questions:

RQ1: How do middle school teachers, students, and parents in China participate in online EFL classrooms during the COVID-19 lockdown?

RQ2: What are the perceptions of online EFL classrooms by middle school English teachers, students, and parents in China during the COVID-19 lockdown?

\section{LITERATURE REVIEW}




\section{A. Classroom Ecology}

The theory of classroom ecology describes the classroom as an organic, complex, and unified micro-ecosystem, similar to a biological ecosystem (Bronfenbrenner, 1976; van Lier., 2004). Chang and Guetl (2007) proposed that a classroom ecology system is composed of two types of units - biotic units and abiotic units. The former refers to the living members such as teachers and students, while the latter represents the non-living parts (i.e., the environment, including tools, technology, facilities, curriculum, etc.). Akin to the biosphere, a slight change of one unit may affect the educational system as a whole (Hastie, 2016), and the interrelationships among different units are the research focuses (Tudor, 2001; van Lier., 1997). Extending the traditional classroom ecology theory, this study considers parents as another participatory unit and explores the three-dimensional model involving teachers, students, and parents in this online classroom ecology under the specific pandemic background. As one of the stakeholder groups, middle school parents play important roles in promoting basic education informatization (Kong, 2017; Lubis \& Lubis, 2020). What's more, many parents worked at home because of the pandemic lockdown, which made it possible for them to be a more active part in their children's online learning.

\section{B. Online Learning}

Online learning is based on the use of electronic equipment or network-based training facilities (Rapanta et al., 2020; Sangrà et al., 2012; Sharma \& Kitchens, 2004). Advantages of online learning have been documented in existing studies. For example, it encourages students to make personal study plans according to their learning styles and endows students with great learning autonomy (Butler, 2012; Jamalpur et al., 2021). In addition, online education allows students to have easy access to teachers' instruction and be exposed to educational environments regardless of where they are (Butnaru et al., 2021; Lehmann \& Chamberlin, 2009). Despite these positive effects, problems emerge in adopting online delivery mode. This instructional approach causes the absence of face-to-face interactions between students and teachers, where students could be more passive in learning (Hrastinski, 2008; Joshi et al., 2020). Students complain about technical hindrances such as unstable connections and inadequate support of hardware and software (Nkonge \& Geuldenzolph, 2006), while teachers report their nonproficient digital skills, additional preparation time for designing a course, and students' procrastination in online learning environment (Keengwe \& Kidd, 2010).

Different from planned online instruction, emergency remote instruction requires unique approaches to teaching and learning (Hodges et al., 2020; Moser et al., 2021). The abrupt shift to online delivery in crises intends to provide temporary access to instruction without deliberate and advanced design (Hodges et al., 2020). As emergency remote instruction manifests differently in divergent contexts, it is of great value to delineate the picture of the online educational ecosystem created by the outbreak of COVID-19 when a large number of online students were involved but the digital transformation was quite rushed (Cen et al., 2020; Hodges et al., 2020; Moser et al., 2021).

\section{Online Foreign Language Education}

Online foreign language education has been found to minimize learners' anxiety (Alhamami, 2019), enrich their learning experiences (Chen, 2017), and increase student-centered activities (Bower, 2017). However, since foreign language may serve as both the instruction and subject matter, teaching and learning online can pose additional challenges for language educators and learners. For foreign language teachers, online teaching influences their traditional communicative teaching paradigm and alternates the way of detecting learners' multimodal feedback about language connotation processing (Gao \& Zhang, 2020; Moorhouse et al., 2021). Also, an effective online foreign language class requires teachers to command solid pedagogical knowledge and skills in explicitly elaborating various language-related content, such as grammar, vocabulary, and cross-cultural information (Moorhouse et al., 2021). Moreover, it is found that the increasing popularity of online English learning in China demands an upgrading technological competency among Chinese EFL teachers (Huang et al., 2021).

For Chinese middle school students, who take English as an exam-based compulsory course, online English learning requires self-regulation competencies and autonomous learning abilities (Pan \& Block, 2011). Problems may emerge in the sudden transition to online English learning because of the absence of face-to-face instructions from teachers. In addition, researchers found that students need to develop behavioral, cognitive, and affective skills to complete online foreign language learning tasks (Luan et al., 2020; Moorhouse et al., 2021). In China, parents highly value their children's English learning and invest heavily in that (Tong et al., 2021). Since parents' active engagement positively affects students' academic success (Marchant et al., 2001), Chinese parents' involvement could be helpful to their children's online English learning.

To comprehensively understand the online EFL classroom ecology in Chinese middle schools, the role of participants including English teachers, students, and parents needs to be well investigated. It is worth exploring how these stakeholders of EFL education dealt with the aforementioned deficiencies and challenges when they switched to online delivery mode during COVID-19 lockdown.

\section{Methodology}

This study adopted quantitative and qualitative methods by conducting surveys and semi-structured interviews. To enhance communication quality, all data were collected in Chinese. 


\section{A. Sample}

A total of 10, 576 questionnaires were collected from all the 14 middle schools, where online EFL teaching was fully enacted, including 420 from English teachers, 5, 556 from students, and 4, 600 from parents. The participants' demographic information is illustrated in Table 1. In addition, five English teachers were recruited to participate in semi-structured interviews considering their gender $\left(\mathrm{N}_{\mathrm{t}-\text { male }}=1 ; \mathrm{N}_{\mathrm{t} \text {-female }}=4\right)$, current teaching grade $\left(\mathrm{N}_{\mathrm{t}-7 \mathrm{th}}=1 ; \mathrm{N}_{\mathrm{t}-8 \mathrm{th}}=2 ; \&\right.$ $\left.\mathrm{N}_{\mathrm{t}-9 \mathrm{th}}=2\right)$, education degree $\left(\mathrm{N}_{\text {associate }}=2 ; \mathrm{N}_{\text {bachelor }}=3\right)$, and years of teaching $\left(\mathrm{N}_{110}=1 ; \mathrm{N}_{11 \sim 19}=2 ; \& \mathrm{~N}_{\geq 20}=2\right)$. Six students were recruited considering their gender $\left(\mathrm{N}_{\mathrm{s}-\text { male }}=3 ; \mathrm{N}_{\mathrm{s}-\text { female }}=3\right)$ and grade $\left(\mathrm{N}_{\mathrm{s}-7 \mathrm{th}}=2 ; \mathrm{N}_{\mathrm{s}-8 \mathrm{th}}=2 ; \& \mathrm{~N}_{\mathrm{s}-9 \mathrm{th}}=2\right)$.

TABLE 1

DEMOGRAPHIC INFORMATION OF SURVEY RESPONDENTS

\begin{tabular}{|c|c|c|}
\hline Participants & Category & $\mathrm{N}(\%)$ \\
\hline \multicolumn{3}{|l|}{ English Teachers } \\
\hline \multirow[t]{2}{*}{ Gender } & Male & $65(15.48)$ \\
\hline & Female & $355(84.52)$ \\
\hline \multirow[t]{3}{*}{ Teaching Grade } & Seven & $127(30.24)$ \\
\hline & Eight & $132(31.43)$ \\
\hline & Nine & $161(38.33)$ \\
\hline \multirow[t]{3}{*}{ Education } & Associate degree & $32(7.62)$ \\
\hline & Bachelor degree & $367(87.38)$ \\
\hline & Master degree and above & $21(5)$ \\
\hline \multirow[t]{5}{*}{ Years of Teaching } & $\leq 5$ years & $61(14.52)$ \\
\hline & $>5$ years, $\leq 10$ years & $43(10.24)$ \\
\hline & $>10$ years, $\leq 15$ years & $54(12.86)$ \\
\hline & $>15$ years, $\leq 20$ years & $58(13.81)$ \\
\hline & $>20$ years & $204(48.57)$ \\
\hline \multicolumn{3}{|l|}{ Students } \\
\hline \multirow[t]{2}{*}{ Gender } & Male & $2,655(47.79)$ \\
\hline & Female & $2,901(52.21)$ \\
\hline \multirow[t]{3}{*}{ Grade } & Seven & $2,182(39.27)$ \\
\hline & Eight & $1,651(29.72)$ \\
\hline & Nine & $1,723(31.01)$ \\
\hline \multicolumn{3}{|l|}{ Parents } \\
\hline \multirow[t]{2}{*}{ Gender } & Male & $1,454(31.61)$ \\
\hline & Female & $3,146(68.39)$ \\
\hline \multirow[t]{3}{*}{ Children's Grade } & Seven & $1,959(42.59)$ \\
\hline & Eight & $1,256(27.30)$ \\
\hline & Nine & $1,385(30.11)$ \\
\hline
\end{tabular}

\section{B. Instruments}

Three surveys for English teachers, students, and parents were designed respectively. Besides the identical introduction of research purpose and respective demographics queries, three surveys have different focuses: English teachers' and students' surveys investigate their respective experiences and perceptions about online teaching and learning, while parents' survey concerns their participation in and perceptions of their children's online EFL learning. The internal consistency of the Likert scale items in each of the three surveys was measured, and the reliability for English teachers', students', and parents' surveys were 0.92, 0.94, and 0.96 respectively, which indicate a strong internal consistency (Hair et al., 1998; Nunnally, 1978). The interview questions for English teachers and students were designed to elicit more detailed responses with different emphases as well.

\section{Data Collection and Analysis}

Before the formal distribution, all three surveys were handed out to three small-scale target groups for a pilot study. After the modification of a few wording issues based on the feedback, the surveys were distributed online through a platform named "Wenjuanxing" (www.wjx.cn) from March $18^{\text {th }}$ to March $25^{\text {th }}$ in 2020. Through the help of Yichang Education Bureau, the survey links were sent to the English Teaching \& Research Groups at all middle schools of the city. Then, the English teachers, students, and parents were invited to finish the questionnaire voluntarily and independently. Their participation and responses were assured anonymity and confidentiality. From March $28^{\text {th }}$ to April $2^{\text {nd }}$ in 2020, eleven interviews were conducted through online voice calls, and each one lasted approximately 20-30 minutes. Before data collection, all participants signed the consent form. No financial compensation was paid to these participants who were instead informed of their contributions to the EFL research community.

After all the data were collected, both quantitative and qualitative data analyses were conducted. First, the quantitative data, collected by the survey, were analysed by using the software SPSS 24 . Descriptive statistical analysis and Kruskal-Wallis Test were conducted to reveal how English teachers, students, and parents participated in online EFL classrooms and perceived this learning mode. Second, the qualitative data, collected from the interview, were transcribed, and content analysis was used for identifying valuable information responding to the research questions. 
After carefully reading the transcript data, we coded the data and sorted them into potential categories, which were further refined and labeled.

\section{RESULTS}

\section{A. Participants in the Online EFL Classroom Ecology}

\section{English Teachers}

The results depicted how English teachers delivered and organized online EFL lectures during the Covid-19 lockdown. It was found that $14.05 \%$ of the surveyed English teachers had online teaching experiences before the pandemic, and more than half $(55.95 \%)$ of the teachers had received technical training from their schools about dealing with the abrupt changes in teaching. Figure 1 (a) shows that multiple types of software were adopted, including Ding Talk, Shiwo, WeChat, and so on. In terms of hardware, $39.52 \%$ of teachers were equipped with more than one device for online teaching, including desktops, laptops, tablets, smartphones, and so on, as presented in Figure 1 (b). About two-thirds of the English teachers (64.29\%) employed live class, a few (11.67\%) recorded the lectures in advance, and the rest $(24.04 \%)$ used public online course clips made by other teachers. During the class, $23.8 \%$ of the teachers opened their cameras to show their images to the class and $27.62 \%$ made explicit explanations with hand drawing. As explained by interviewee Li (Teacher 1) in the interview, "I find it not easy to write to students in online classes, much more difficult than using a blackboard offline." As many as $85.48 \%$ of teachers reported that they used less than two hours in preparing offline lessons, and $14.52 \%$ used two hours and above; but when they prepared the online ones, the proportion of the corresponding two groups was close, $51.9 \%$ and $48.09 \%$ respectively. Interviewee Xie (Teacher 3) illustrated his experience in the interview, "I spent more time in designing my online classes to make them as interesting as possible." Another participant, Qin (Teacher 5), expressed her concerns about online teaching preparation, "I felt frustrated when my online classes didn't go as well as expected, although I had put a lot of efforts in preparing them and approximating previous school teaching."

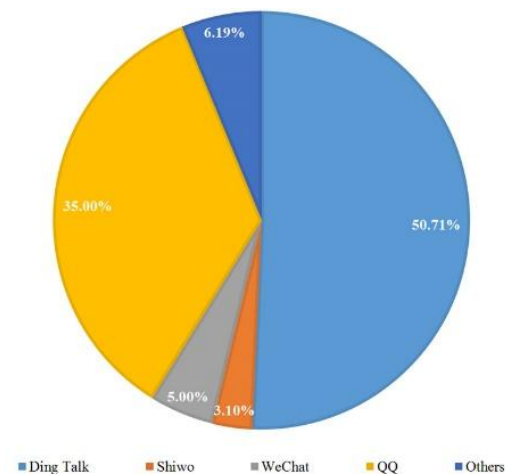

(a)

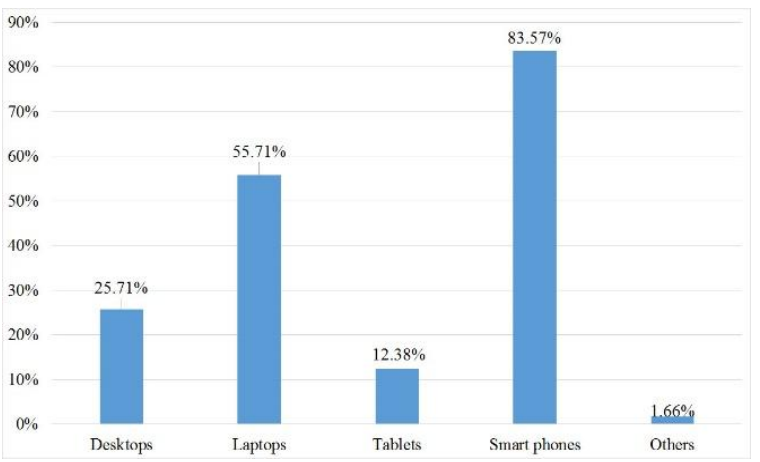

(b)

Figure 1. Software and hardware used for online EFL teaching

\section{Students}

The results demonstrated that $78.74 \%$ of the surveyed students had previous online English learning experiences. 98.67\% had an Internet connection and at least one electronic device at home for online learning, while the rest got access to online classes by using the Internet or hardware of others, such as neighbors or community offices. Under this online English learning context, 78.8\% of the students indicated that they were able to follow the English teacher's instruction and finish the online learning tasks on time. Figure 2 shows students' frequency of being fully concentrated in EFL classrooms, indicating that $28.09 \%$ of them could not always follow the English teacher. In the interview, interviewee Shu (Student 1) explained, “the teacher's explanation about long or complex English sentences made it hard for me to follow." The data also show students' first choices to address questions in online EFL classrooms: about onethird $(36.16 \%)$ of them searched answers on the Internet independently, another one-third (32.96\%) turned to their English teachers, $28.01 \%$ talked to their classmates, and $2.8 \%$ gave up. Although students were able to communicate with their teachers and classmates, they still had difficulties in solving language learning problems. Interviewee Tu (Student 4) said, "it is hard to clarify my questions about English well online, which is less effective than in real classrooms." 


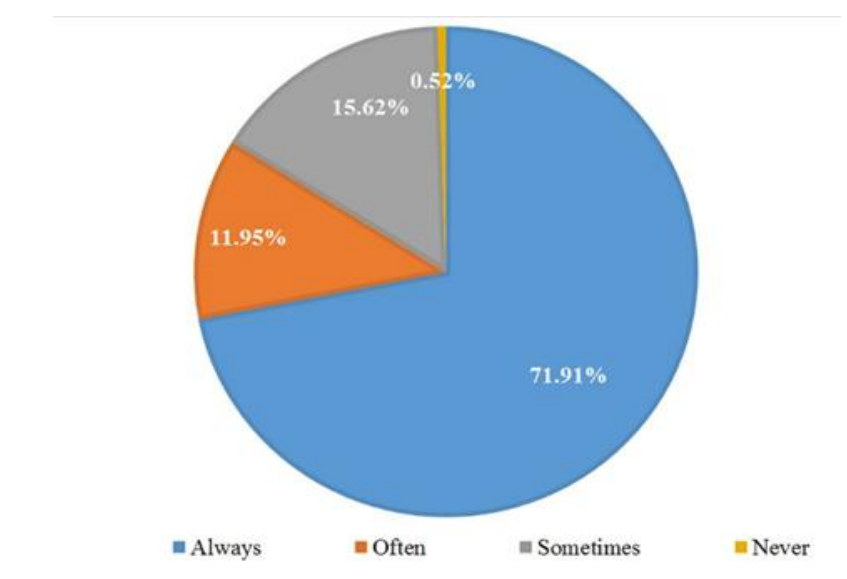

Figure 2. Frequency of students being fully concentrated in EFL classrooms

\section{Parents}

The quarantine policies during the pandemic made it possible for many Chinese parents to spend more time with their children at home. $88.02 \%$ of the surveyed parents reported that they were invited to participate in online classroom management by their children's English teachers. As demonstrated in Figure 3, about one-third (33.39\%) of the parents were always present in online EFL classrooms with their children and about three-fifths often $(32.02 \%)$ or occasionally (28.13\%). However, English teachers believed that parents' support could be enhanced. 67.86\% of them agreed that parents did not effectively support their children in online EFL learning. In the interview, interviewee Xie (Teacher 3) expressed the doubt about parents' qualification in assisting in students' English learning at home: "Some parents' English literacy was not good, and they didn't know how to cooperate with the teachers."

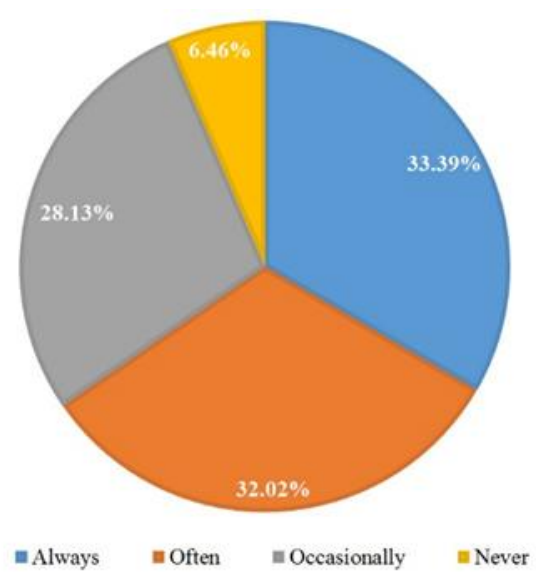

Figure 3. Frequency of parents participating in online EFL classrooms

\section{B. Teachers, Students, and Parents' Perceptions of Online EFL Classrooms}

\section{Students' Learning Performance}

In terms of students' learning engagement and learning outcome in online EFL classrooms, the results in Table 2 indicate that the mean scores of English teachers were lower than three (neutral), while that of students and parents were above three. Kruskal-Wallis Test shows that the evaluations among the three groups were significantly different (Adj. $\mathrm{p}<.05$ ). Parents evaluated their children's EFL learning engagement lower than students themselves, while the results of learning outcomes were the opposite. 
TABLE 2

PERCEPTIONS OF STUDENTS' EFL LEARNING ENGAGEMENT AND OUTCOME

\begin{tabular}{|c|c|c|c|c|}
\hline \multirow{2}{*}{ Aspect } & Groups & \multirow{2}{*}{ Mean } & \multicolumn{2}{|c|}{ Kruskal-Wallis Test } \\
\cline { 3 - 5 } & & & Paired Test & Adj. Sig. \\
\hline \multirow{2}{*}{ Learning engagement } & $\mathrm{T}^{*}$ & 2.82 & $\mathrm{~T}-\mathrm{P}$ & $.000^{* *}$ \\
\cline { 2 - 5 } & $\mathrm{S}$ & 4.28 & $\mathrm{~T}-\mathrm{S}$ & $.000^{* *}$ \\
\cline { 2 - 5 } & $\mathrm{P}$ & 3.99 & $\mathrm{~S}-\mathrm{P}$ & $.000^{* *}$ \\
\hline \multirow{2}{*}{ Learning outcome } & $\mathrm{T}$ & 2.89 & $\mathrm{~T}-\mathrm{P}$ & $.000^{* *}$ \\
\cline { 2 - 5 } & $\mathrm{S}$ & 3.87 & $\mathrm{~T}-\mathrm{S}$ & $.000^{* *}$ \\
\cline { 2 - 5 } & $\mathrm{P}$ & 4.10 & $\mathrm{~S}-\mathrm{P}$ & $.000^{* *}$ \\
\hline
\end{tabular}

*T: Teacher, S: Student, P: Parent

$* * \mathrm{p}<.05$

\section{Teacher-Student Interactions}

The three groups' perceptions of teacher-student interactions in terms of in-class interaction, out-of-class interaction, and teachers' feedback on homework were examined. Table 3 shows that English teachers' mean scores were significantly lower than that of students and parents in all three aspects (Adj. p<.05). Also, parents' mean score was significantly higher than students' regarding the after-class interaction, and their perceptions about the other two interaction aspects had no difference.

TABLE 3

PERCEPTIONS OF TEACHER-STUDENT INTERACTIONS IN THREE ASPECTS

\begin{tabular}{|c|c|c|c|c|}
\hline \multirow{2}{*}{ Aspect } & Groups & \multirow{2}{*}{ Mean } & \multicolumn{2}{c|}{ Kruskal-Wallis Test } \\
\cline { 3 - 5 } & & & Paired Test & Adj. Sig. \\
\hline \multirow{3}{*}{ In-Class Interaction } & $\mathrm{T}$ & 3.54 & $\mathrm{~T}-\mathrm{P}$ & $.000^{*}$ \\
\cline { 2 - 5 } & $\mathrm{S}$ & 4.23 & $\mathrm{~T}-\mathrm{S}$ & $.000^{*}$ \\
\cline { 2 - 5 } & $\mathrm{P}$ & 4.27 & $\mathrm{~S}-\mathrm{P}$ & .281 \\
\hline \multirow{2}{*}{ After-Class Interaction } & $\mathrm{T}$ & 3.8 & $\mathrm{~T}-\mathrm{P}$ & $.000^{*}$ \\
\cline { 2 - 5 } & $\mathrm{S}$ & 4.02 & $\mathrm{~T}-\mathrm{S}$ & $.000^{*}$ \\
\cline { 2 - 5 } & $\mathrm{P}$ & 4.36 & $\mathrm{~S}-\mathrm{P}$ & $.000^{*}$ \\
\hline \multirow{2}{*}{ Feedback about Homework } & $\mathrm{T}$ & 3.11 & $\mathrm{~T}-\mathrm{P}$ & $.000^{*}$ \\
\cline { 2 - 5 } & $\mathrm{S}$ & 4.52 & $\mathrm{~T}-\mathrm{S}$ & $.000^{*}$ \\
\cline { 2 - 5 } & $\mathrm{P}$ & 4.54 & $\mathrm{~S}-\mathrm{P}$ & .147 \\
\hline
\end{tabular}

\section{Overall Satisfaction}

As demonstrated in Table 4, English teachers, students, and parents positively evaluated the online EFL classrooms in general as the means of their satisfaction were all above three out of five (very positive) based on the Likert scale. However, the Kruskal-Wallis Test shows that the three groups significantly varied in their overall satisfaction (Adj. $\mathrm{p}<.05)$, and from the lowest to the highest are: English teachers, parents, and students.

TABLE 4

OVERALL SATISFACTION OF ONLINE EFL CLASSROOMS

\begin{tabular}{|c|c|c|c|}
\hline \multirow{2}{*}{ Groups } & \multirow{2}{*}{ Mean } & \multicolumn{2}{|c|}{ Kruskal-Wallis Test } \\
\cline { 3 - 4 } & & Paired Test & Adj. Sig. \\
\hline $\mathrm{T}$ & 3.33 & $\mathrm{~T}-\mathrm{P}$ & $.000 *$ \\
\hline $\mathrm{P}$ & 3.9 & $\mathrm{~S}-\mathrm{P}$ & $.000^{*}$ \\
\hline $\mathrm{S}$ & 3.99 & $\mathrm{~T}-\mathrm{S}$ & $.000^{*}$ \\
\hline \multicolumn{3}{|c}{} \\
\hline
\end{tabular}

\section{Major Concerns}

Figure 4 shows the major concerns of three groups regarding online EFL classrooms during the lockdown. Some proposed concerns include teachers' worries about their eyesight, students' complaints about lacking learning atmosphere, and parents' worries about their inability of helping their children with English learning. Besides these concerns, $58.86 \%$ of students and $75.85 \%$ of parents suggested that teachers should repeat the online learning content when schools were reopened. However, English teachers did not reach a consensus regarding this issue with only $50.71 \%$ supporting the suggestion. Interviewee Qin (Teacher 5) was unwilling to lecture on the same content and she explained, "there won't be enough time if we have to cover both of the old and new knowledge based on the fixed curriculum". 


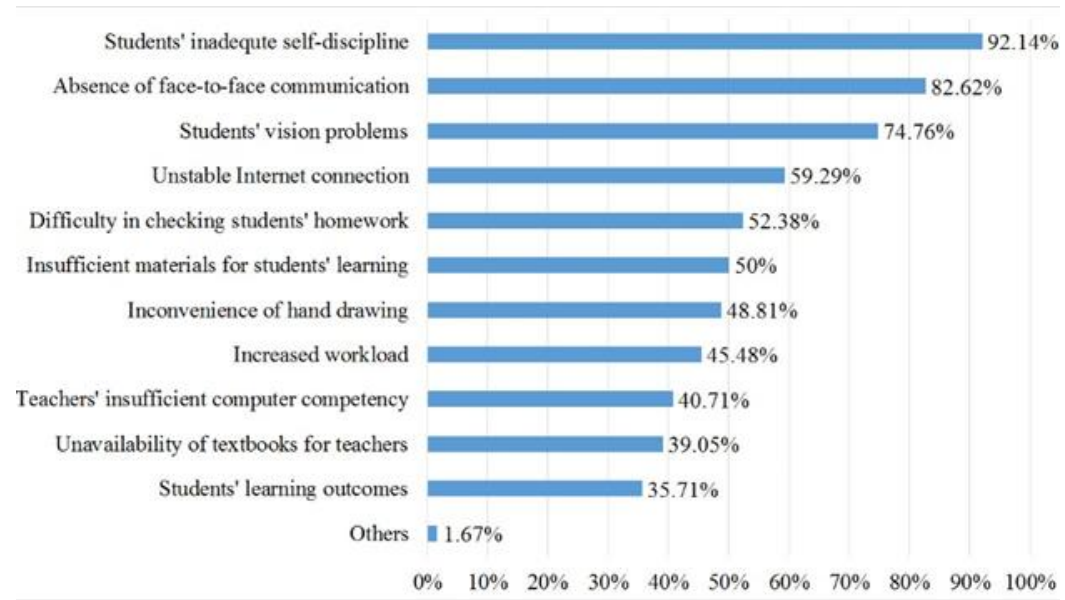

(a) Teachers

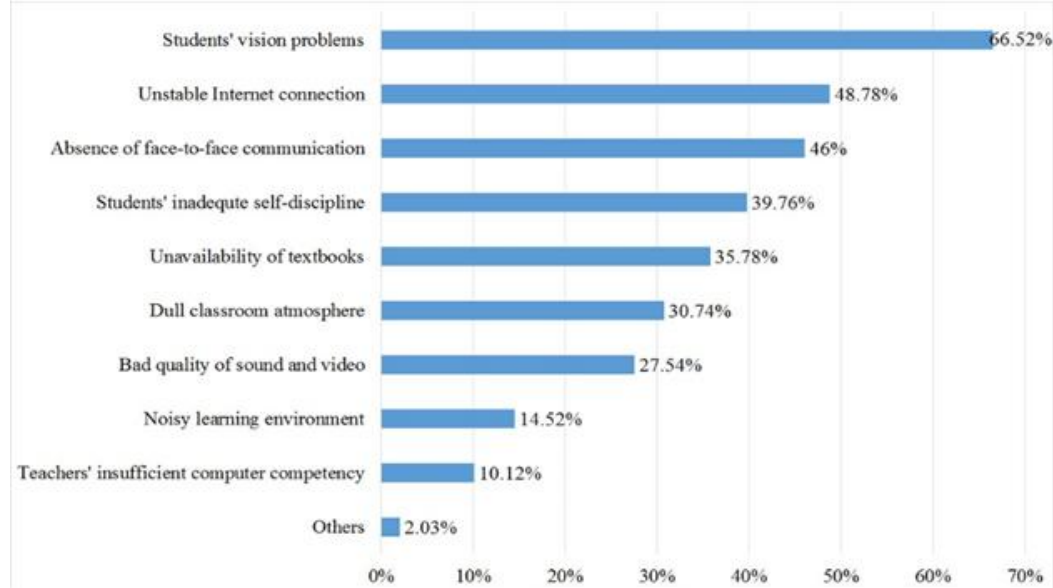

(b) Students

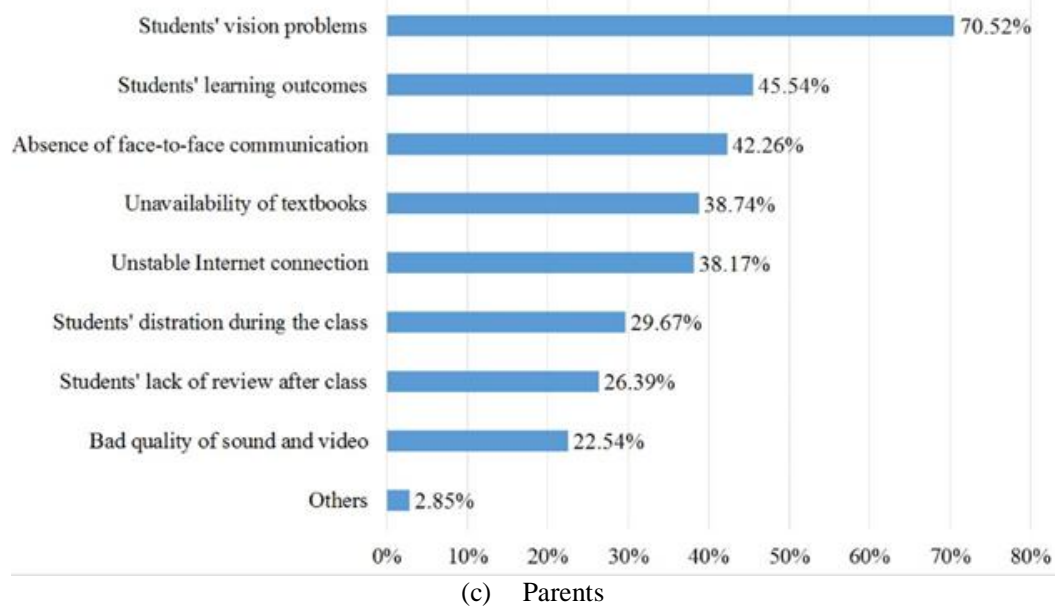

Figure 4. Major concerns about online EFL classrooms from three groups of participants

\section{Discussion}

Through surveys and semi-structured interviews, this study illustrated the online EFL classroom ecology during the COVID-19 lockdown and perceptions of this delivery mode held by English teachers, students, and parents. Although the non-living components of the online EFL classroom ecology, including Internet connection and electronic devices, were inconvenient to some students, this did not threaten the classroom ecological balance significantly. The living components, i.e., English teachers, students, and parents, also adapted themselves to this abrupt change in different ways and contributed to the online classroom ecology. When middle school foreign language education turns to online due to the sudden public crisis, the characteristics of this subject and learners pose a challenge to the realization of effective teaching and learning. We need to specifically identify the problems of the online EFL classroom ecology and explore potential solutions. 
The data reveals that English teachers' teaching practice was reshaped dramatically during this health emergency. Although about $15 \%$ of them had previous online teaching experience and half of them had received training and support at different levels, they struggled with increased workload of online class preparation, online teaching tools, and the anxiety caused by such problems. In light of this, future language teacher training could consider expanding the scope of trainees and enhancing programs of technology-related pedagogy and stress coping strategies. Echoing suggestions by Gyampoh (2020), education institutions should consider developing various training on teachers' online teaching ability to deal with the possible changes in the way of emergency teaching. Given that language acquisition requires considerable communication and interaction (Mackey, 2020; Pishghadam et al., 2019), foreign language teachers might need to pay special attention to exploring effective pedagogy in emergency-induced online language education.

The data also shows that students' learning experience was impacted by this abrupt change. About one-third of the students had difficulties in concentrating on the online EFL lectures. Language teachers may consider exploring multiple ways to enhance students' online learning engagement, such as employing student-centered activities (Parsons et al., 2018), applying storyline-oriented instructional designs (Ahlquist, 2015), involving game-based teaching interventions (Yin \& Chen, 2020), etc. Since taking online classes allows students to have easier access to diverse learning resources, which could also be a potential distraction, teachers should provide students with more guidance on Internet information discrimination and independent study ability development. Meanwhile, parents may play a more active role in helping their children with online classroom engagement and process negative emotions related to online EFL classes.

Moreover, this study identified parents as another active participant in the online EFL classroom ecology during the lockdown. The findings revealed that more than half of parents could always or often accompany their children in online EFL classes, showing their willingness to be involved. Previous findings explained that Chinese parents tend to devote effort to the educational process since they highly value their children's academic achievement (Cheung \& Pomerantz, 2011). Also, parental involvement in academic activities is one of the predictors of students' English learning achievement (Wang, 2015). Despite parents' frequent participation in online EFL classrooms, English teachers indicated there was a mismatch between parents' assistance and students' learning and expected more effective involvement of the parents. Taking parents' willingness and capability into account, teachers may consider designing some home-based English learning activities with parent-friendly instructions, such as reading aloud, singing songs, and playing games (Dixon \& Wu, 2014; Tong et al., 2021). Meanwhile, teachers should balance the expectations and be aware of the limitations in parents' engagement resulting from lacking time or English literacy. Promoting a mutual understanding and collaboration between teachers and parents seems necessary for offering better academic and psychological support to students in such a critical time.

In addition, this study finds that English teachers, students, and parents generally held a positive view of online delivery mode during the lockdown. However, English teachers' rating was lower than that of students and parents. Likewise, the teachers were less satisfied with students' learning performance and teacher-student interaction than students and parents. The discrepancy in the perceptions of students' learning performance necessitates the development and implementation of comprehensive academic assessments suitable for online EFL education contexts, so that all these three groups can be informed of the learning progress in straightforward and simultaneous ways. The lower evaluation of interaction from teachers could be impacted by their insufficient experiences in online teaching. Some of them might attempt to replicate or approximate school classrooms activities, but the interaction effects could not reach their expectations. However, students' and parents' high evaluation suggested that teachers could be less anxious about online EFL classroom interaction. There were also some differences in teachers', students', and parents' major concerns about online EFL classrooms. English teachers expressed their higher concerns about students' lack of self-control in online learning. They could try to explore effective approaches to cultivating students' self-regulatory beliefs and habits with joint efforts of parents (Zimmerman, 2002). Students and parents were more concerned with students' vision damage. The alternatives include shortening the online session duration and monitoring students' technology use (Dong et al., 2020; Nouwen \& Zaman, 2018). Both teachers and school policymakers need to carefully address this issue in future program designs (Dong et al., 2020). Besides that, students were more concerned with unstable Internet connections as their learning experiences were directly related to it. Teachers can pay attention to these technical issues constantly and provide recorded lectures after class. It is noteworthy that all three groups worried about the lack of faceto-face communication and learning materials such as textbooks. English teachers should consider showing their images more often, encouraging students to do so as well, and incorporating verbal and non-verbal interactions to enhance simultaneous exchanges (Cheung, 2021). Besides, more online English learning materials, like E-books, should be developed and prepared in case of emergency-induced online learning.

\section{CONCLUSION}

The abrupt switch to online EFL classrooms during the COVID-19 lockdown has posed great challenges to different participants. Aiming to promote a comprehensive understanding of emergency EFL online education in China and provide insights for language educators worldwide, this study explored the unique classroom ecology by investigating the participation and perceptions of middle school English teachers, students, and parents in Yichang, Hubei. The 
findings depicted how these three groups adapted themselves in this online delivery mode and their perceptions towards it. English teachers' evaluations of students' learning performance, teacher-student interactions, and overall satisfaction were lower than that of the other two groups. Meanwhile, the three groups have some shared and different concerns about online EFL classrooms. In the end, implications drawn from the above findings were discussed from several perspectives, including teachers, parents, school policymakers, and learning material developers. This study has two limitations. First, as we failed in recruiting any parents in interviews, this study lacks qualitative data from parents' perspectives. Second, the self-reported data from surveys and interviews may have a socially desirable bias (Dong et al., 2020). Future studies may consider involving in-depth data from parents and adopting other methods such as in-class observations or peer evaluations for data triangulation.

\section{REFERENCES}

[1] Ahlquist, S. (2015). The Storyline approach: promoting learning through cooperation in the second language classroom. Education, 43 (1), 40-54.

[2] Alhamami, M. (2019). Learners' beliefs about language-learning abilities in face-to-face \& online settings. International Journal of Educational Technology in Higher Education, 16(1), Article 31. https://doi.org/10.1186/s41239-019-0162-1

[3] Bower, M. (2017). Design of Web 2.0 Enhanced Learning. Emerald Publishing Limited.

[4] Bronfenbrenner, U. (1976). The ecology of human nature: Experiments by nature and design. Cambridge, MA: Harvard University Press.

[5] Butler, K. C. (2012). A model of successful adaptation to online learning for college-bound Native American high school students. Multicultural Education \& Technology Journal, 6(2), 60-76.

[6] Butnaru, G. I., Niță, V., Anichiti, A., \& Brînză, G. (2021). The Effectiveness of Online Education during Covid 19 PandemicA Comparative Analysis between the Perceptions of Academic Students and High School Students from Romania. Sustainability, 13(9), Article 5311. https://www.mdpi.com/2071-1050/13/9/5311

[7] Cen, X., Dong, S., Rong, M., Fekete, G., Baker, J., Yang, S., \& Gu, Y. (2020). The Online Education Mode and Reopening Plans for Chinese Schools During the COVID-19 Pandemic: A Mini Review. Frontiers in Public Health, 8, Article 566316. https://doi.org/10.3389/fpubh.2020.566316

[8] Chang, V., \& Guetl, C. (2007). E-Learning Ecosystem (ELES) - A Holistic Approach for the Development of more Effective Learning Environment for Small-and-Medium Sized Enterprises (SMEs). In Chang, E. and Hussain, F. K. (Eds), Inaugural IEEE International Conference on Digital Ecosystems and Technologies (pp. 440-445). Cairns.

[9] Chen, K. T. C. (2017). Examining EFL instructors' and students' perceptions and acceptance toward M-learning in higher education. Universal Access in the Information Society, 16(4), 967-976.

[10] Cheung, A. (2021). Synchronous online teaching, a blessing or a curse? Insights from EFL primary students' interaction during online English lessons. System, 100, Article 102566. https://doi.org/10.1016/j.system.2021.102566

[11] Cheung, C. S., \& Pomerantz, E. M. (2011). Parents' Involvement in children's learning in the United States and China: A longitudinal investigation. Child Development, 82, 932-950.

[12] Cui, Y. (2021). Perceived Learning Outcomes and Interaction Mode Matter: Students' Experience of Taking Online EFL Courses During COVID-19. English Language Teaching, 14(6), 84-95.

[13] Dixon, L. Q., \& Wu, S. (2014). Home language and literacy practices among immigrant second-language learners. Language Teaching, 47(4), 414-449.

[14] Dong, C., Cao, S., \& Li, H. (2020). Young children's online learning during COVID-19 pandemic: Chinese parents' beliefs and attitudes. Children and Youth Services Review, 118, Article 105440. https://doi.org/10.1016/j.childyouth.2020.105440

[15] Gao, L. X., \& Zhang, L. J. (2020). Teacher Learning in Difficult Times: Examining Foreign Language Teachers' Cognitions About Online Teaching to Tide Over COVID-19. Frontiers in Psychology, 11, Article 54963. https://doi.org/10.3389/fpsyg.2020.549653

[16] Gyampoh, A. O. (2020). Tutor perception on personal and institutional preparedness for online teaching-learning during the COVID-19 crisis: The case of Ghanaian Colleges of Education. African Educational Research Journal, 8(3), 511-518.

[17] Hair Jr., J. F., Anderson, R. E., Tatham, R. L., \& Black, W. C. (1998). Multivariate data analysis. Englewood Cliffs, NJ: Prentice-Hall.

[18] Hastie, P. (2016). The classroom ecology paradigm and its contribution to understanding context in physical education. Recherches \& éducations, 15, 29-50.

[19] Hodges, C. B., Moore, S., Lockee, B. B., Trust, T., \& Bond, M. A. (2020). The difference between emergency remote teaching and online learning. Retrieved August 25, 2021, from Educause Review website: https://er.educause.edu/articles/2020/3/thedifference-between-emergency-remote-teaching-and-online-learning.

[20] Huang, F., Teo, T., \& Guo, J. (2021). Understanding English teachers' non-volitional use of online teaching during the COVID-19 pandemic: A Chinese study. System, 101, Article 102574. https://doi.org/10.1016/j.system.2021.102574

[21] Hrastinski, S. (2008). What is online learner participation? A literature review. Computers \& Education, 51(4), 1755-1765. https://doi.org/https://doi.org/10.1016/j.compedu.2008.05.005

[22] Jamalpur, B., Kafila, Chythanya, K. R., \& Kumar, K. S. (2021). A comprehensive overview of online education-Impact on engineering students during COVID-19. Materials Today: Proceedings. https://doi.org/10.1016/j.matpr.2021.01.749

[23] Joshi, O., Chapagain, B., Kharel, G., Poudyal, N. C., Murray, B. D., \& Mehmood, S. R. (2020). Benefits and challenges of online instruction in agriculture and natural resource education. Interactive Learning Environments, 1-12. https://doi.org/10.1080/10494820.2020.1725896

[24] Keengwe, J., \& Kidd, T. (2010). Towards best practice in online learning and teaching in higher education. Journal of Online Learning and Teaching, 6 (2), 533-541. 
[25] Kong, S. C. (2017). Parents' perceptions of e-learning in school education: implications for the partnership between schools and parents. Technology Pedagogy and Education, 27(1), 15-31. https://doi.org/10.1080/1475939X.2017.1317659

[26] Lehmann, K., \& Chamberlin, L. (2009). Making the Move to eLearning: Putting Your Course Online. Lanham, MD: Rowman \& Littlefield Publishers.

[27] Luan, L., Hong, J. C., Cao, M., Dong, Y., \& Hou, X. (2020). Exploring the role of online EFL learners' perceived social support in their learning engagement: a structural equation model. Interactive Learning Environments, 1-12. https://doi.org/10.1080/10494820.2020.1855211

[28] Lubis, A. H. \& Lubis. Z. (2020). Parent's perceptions on e-learning during COVID-19 pandemic in Indonisia. Journal of Critical Reviews, 7(18), 3599-3607.

[29] Mackey, A. (2020). Interaction, feedback and task research in second language learning: Methods and design. Cambridge University Press.

[30] Marchant, G. J., Paulson, S. E., \& Rothlisberg, B. A. (2001). Relations of middle school students' perceptions of family and school contexts with academic achievement. Psychology in the Schools, 38(6), 505-519.

[31] Moorhouse, B., Li, Y., \& Walsh, S. (2021). E-Classroom Interactional Competencies: Mediating and Assisting Language Learning During Synchronous Online Lessons. RELC Journal. Advance online publication. https://doi.org/10.1177/0033688220985274

[32] Moser, K. M., Wei, T., \& Brenner, D. (2021). Remote teaching during COVID-19: Implications from a national survey of language educators, System, 97, Article 102431. https://doi.org/10.1016/j.system.2020.102431

[33] Nkonge, B., \& Geuldenzolph, L. (2006). Best practices in online education: Implications for policy and practice. Business Education Digest, 15, 42-53.

[34] Nouwen, M., \& Zaman, B. (2018). Redefining the role of parents in young children's online interactions. A value-sensitive design case study. International Journal of Child-Computer Interaction, 18, 22-26. https://doi.org/10.1016/j.ijcci.2018.06.001.

[35] Nunnally, J. C. (1978). Psychometric theory (2nd ed.). New York: McGraw-Hill.

[36] Osamudiamen, E., Chukwunonso, O. A., Francis, I., Iwebuke A. F., \& Sheena, O. E. (2021). Evaluating the impact of COVID19 pandemic lockdown on education in Nigeria: Insights from teachers and students on virtual/online learning. Bulletin of the National Research Centre, 45(1). DOI: 10.1186/s42269-021-00538-6

[37] Pan, L., \& Block, D. (2011). English as a "global language" in China: An investigation into learners' and teachers' language beliefs. System, 39 (3), 391-402.

[38] Parsons, S. A., Vaughn, M., Scales, R. Q. Gallagher, M. A., Parsons, A. W., Davis, S. G., Pierczynski, M., \& Allen, M. (2018). Teachers' instructional adaptations: A research synthesis. Review of Educational Research, 88(2), 205-242.

[39] Patricia, A. (2020). College Students' Use and Acceptance of Emergency Online Learning Due to COVID-19. International Journal of Educational Research Open, 1, Article 10011. https://doi.org/10.1016/j.ijedro.2020.100011

[40] Pishghadam, R., Derakhshan, A., \& Zhaleh, K. (2019). The interplay of teacher success, credibility, and stroke with respect to EFL students' willingness to attend classes. Polish Psychological Bulletin, 50 (4), 284-292.

[41] Rapanta, C., Botturi, L., Goodyear, P., Guàrdia, L., \& Koole, M. (2020). Online University Teaching During and After the Covid-19 Crisis: Refocusing Teacher Presence and Learning Activity. Postdigital Science and Education, 2(3), 923-945.

[42] Russell, V. (2020). Language anxiety and the online learner. Foreign Language Annals, 53 (2), 338-352.

[43] Sangrà, A., Vlachopoulos, D., \& Cabrera, N. (2012). Building an Inclusive Definition of E-Learning: An Approach to the Conceptual Framework. International Review of Research in Open and Distance Learning, 13, 145-159.

[44] Sharma, S., \& Kitchens, F. (2004). Web services architecture for m-learning. Electronic Journal of e-Learning, 2 (1), $203-216$.

[45] Tong, F., Zhang, H., Zhen, F., Irby, B. J., \& Lara-Alecio, R. (2021). Supporting home literacy practices in promoting Chinese parents' engagement in their children's English education in low-SES families: An experimental study. International Journal of Educational Research, 109, Article 101816. https://doi.org/10.1016/j.ijer.2021.101816

[46] Tudor, I. (2001). The dynamics of the language classroom. Cambridge: Cambridge University Press.

[47] van Lier, L. (1997). Observation from an Ecological Perspective. TESOL Quarterly, 31(4), 783-787.

[48] van Lier, L. (2004). The ecology and semiotics of language learning: A sociocultural perspective. Norwell, MA: Kluwer Academic Publishers.

[49] Wang, Y. (2015). A trend study of the influences of parental expectation, parental involvement, and self-efficacy on the English academic achievement of Chinese eighth graders. International Education, 44(2), 45-68.

[50] Yang, X., Li, D., Liu, X., \& Tan, J. (2020). Learner behaviors in synchronous online prosthodontic education during the 2020 COVID-19 pandemic. J Prosthet Dent. Advance online publication. https://doi.org/10.1016/j.prosdent.2020.08.004

[51] Yin, H., \& Chen, Y. (2020). How gamification affects students' engagement and language learning beliefs in pre-class learning of flipped EFL courses: A theoretical analysis. In Proceedings of the 2020 The 2nd World Symposium on Software Engineering (pp. 211-215). Association for Computing Machinery.

[52] Zimmerman, B. (2002). Becoming a Self-Regulated Learner: An Overview. Theory into Practice, 41(2), 64-70.

Shuang Zhao is a postgraduate student at College of Humanities and Social Sciences in Harbin Institute of Technology, Shenzhen, China. Her research interest is in educational technology and second language acquisition.

Luying Zhang is a postgraduate student at College of Humanities and Social Sciences in Harbin Institute of Technology, Shenzhen, China. Her research interest is in educational technology and second language acquisition.

Yang Chen, $\mathrm{Ph}$. D, is an associate professor at College of Humanities and Social Sciences in Harbin Institute of Technology, Shenzhen, China. Her research focuses include educational technology, ecology communication, and second language acquisition. 